\title{
A PROFILE OF AN "IDEAL" HIV AND AIDS WORKPLACE PROGRAMME: THEORY AND PRACTICE
}

\section{Annemarie Naude, Mike Weyers}

\section{INTRODUCTION}

The HIV and AIDS pandemic is having a significant impact on South Africa's public and private sectors. Because it primarily affects working-age adults, its impact is seen in an increase in absenteeism and sick leave, a faster staff turnover rate due to early deaths, more employees placed on disability pensions, lowered staff morale and greater pressure on employee benefits funds (Department of Labour, 2003). To counteract these trends, the workplace has a vital role to play in preventing infection amongst staff members and to deal effectively with those who do become infected. This usually takes the form of an HIV and AIDS workplace programme.

In spite of the increasing number of workplace programmes currently being developed and implemented in South Africa, little research has been undertaken on their effectiveness. What has especially been lacking is empirical data on the components that would make up an "ideal" programme. This article aims to address this deficiency by providing a profile of such a programme. It could at the same time function as a set of criteria against which existing programmes could be benchmarked.

Before the nature and content of an ideal programme are explained, it is first necessary to provide a short overview of the research design and procedure that were followed.

\section{RESEARCH DESIGN AND PROCEDURE}

The development of an "ideal" HIV and AIDS workplace programme formed part of a larger study into the current programme of the South African Police Service (SAPS). The following exposition will, however, only focus on the aim and objectives, design and procedure of that part of the study that dealt with the conceptualisation of an ideal programme.

\section{Aims and objectives}

The main aim of the study was to delineate the nature of, and general requirements for, a successful HIV and AIDS workplace programme. It attempted to identify both the required constituent components and their relative priority.

\section{Research strategy and design}

The research strategy could be described as exploratory in nature with a programme evaluation focus (De Vos, 2005:367; Grinnell, 2001:535). Data collection encompassed a literature study that was combined with structured interviews with key informants in the field of HIV and AIDS work (Delport, 2005:159-191; Fouché, 2005:267-285). The interviews also utilised some elements of the critical incident technique (Weyers \& Van den Berg, 2006:178).

\section{Research procedure}

The study consisted of three phases. In the first the literature on the nature and components of successful HIV and AIDS workplace programmes was analysed. The data were drawn from fields as diverse as generic and occupational social work, workplace and work-wellness programmes, management and HIV and AIDS-related services in general. It covered research reports, books, scientific journals of both South African and international origin, and internet databases. This process produced a list of 10 potential programme components. 
In order to prioritise the components and to identify the main success factors of such programmes, a series of in-depth, structured interviews were held with 33 key informants from South Africa's public and private sectors. The participants were from the Gauteng and KwaZulu-Natal provinces. The structured nature of the interviews made it possible to quantify most of the responses that were generated.

The results of the literature study were compared with those of the in-depth interviews (Grinnell, 2001:535). From this it was possible to produce a profile of an "ideal" HIV and AIDS workplace programme that would best suit South African circumstances.

\section{Participants in the research}

Two criteria were used to identify and select the participants who would most probably provide the "best" data on effective programmes.

They, firstly, had to be key role-players in the various types of HIV and AIDS workplacerelated programmes that are available locally. Interviewees were consequently drawn from local authorities, the business sector, medical institutions, tertiary education, non-government organisations (NGOs) and several government departments (Table 1). Because of the need to also include "frontline" workers and the fact that the study originated in the SAPS, representatives from this organisation made up the majority of the government participants.

The second criterion was that the participants had to work in either the Gauteng or the KwaZulu-Natal (KZN) provinces. The reasons for this choice was that, although both provinces had well-developed organisational infrastructures and housed the head offices of various organisations, they would probably reflect different approaches to dealing with workplace HIV and AIDS issues. This assumption was based in part on the fact that organisations in Gauteng have better access to specialised HIV and AIDS-related support services than other provinces.

During the period 21/02/2006 to 14/03/2007 a total of 33 representatives of the public and private sector were selected and mobilised on an availability basis. A breakdown of the sectors which these participants represent is provided in Table 1.

TABLE 1

A PROFILE OF THE PARTICIPANTS

\begin{tabular}{|l|l|}
\hline \multicolumn{1}{|c|}{ Organisation } & Sub-total \\
\hline South African Police Service (SAPS) & $11(33.33 \%)$ \\
\hline $\begin{array}{l}\text { Other government departments } \\
\text { (Departments of Agriculture, Conservation and the Environment; Community Safety; } \\
\text { Education; Health; Housing; Roads and Works; Social Development; Transport) }\end{array}$ & $8(24.24 \%)$ \\
\hline $\begin{array}{l}\text { Local Authorities } \\
\text { (Cities of Tshwane and Johannesburg) }\end{array}$ & $2(6.06 \%)$ \\
\hline $\begin{array}{l}\text { Tertiary Education } \\
\text { (Universities of the Witwatersrand \& KZN) }\end{array}$ & $2(6.06 \%)$ \\
\hline $\begin{array}{l}\text { Business Sector / Medical Institutions } \\
\text { (Centre for HIV/AIDS networking (HIVAN); Daimler Chrysler (SA); Netcare; S \& T } \\
\text { Health Information Services; SA Business Coalition on HIV/AIDS (SABCOHA)) }\end{array}$ & $5(15.15 \%)$ \\
\hline $\begin{array}{l}\text { Non-Governmental Organisations (NGOs) } \\
\text { (KZN Blind and Deaf Society; Muslim AIDS Programme; Phoenix Child \& Family } \\
\text { Welfare Society; Zoë Life) }\end{array}$ & $5(15.15 \%)$ \\
\hline Total & $\mathbf{3 3 ( 1 0 0 \% )}$ \\
\hline
\end{tabular}


Although it was not the purpose of the study to mobilise participants who would be representative of the whole HIV and AIDS workplace field, the selection process did produce a relatively large number of key role-players from a diversity of settings. Because the "mix" of representatives also stretched from the higher management echelons to "frontline" workers, it was expected that they would approach the same issues from different perspectives. The data indicated that this was indeed the case.

\section{Data collection instruments}

In order to arrive at quantifiable and comparable answers to the two primary research questions, viz. "What are the key components of your HIV and AIDS workplace programme?" and "What do you consider as the key determinants for the success of your programme?", a structured schedule was developed for the in-depth interviews. This schedule, which was based on the literature review, and contained six core/initial and 21 follow-up questions (Table 2). The initial questions were sent to all the participants and, depending on their responses, appropriate follow-up questions were then selected from the available list.

\section{THE COMPONENTS OF AN "IDEAL" HIV AND AIDS WORKPLACE PROGRAMME: THEORY}

An HIV and AIDS workplace programme could be viewed as a formal organisational structure that utilises a set plan to prevent new HIV infections amongst employees, to provide care and support for those who are infected or affected by it, and to manage the impact of the epidemic on the organisation (Cape Gateway, 2004:1; Department of Labour, 2003:40; James, 2005:24). From the in-depth analysis of the "success" literature it emerged that effective programmes consisted of at least 10 components. They are:

- a comprehensive HIV and AIDS policy;

- management involvement and strategies;

- a communication and marketing strategy;

- prevention/awareness initiatives/programmes;

- specialised education and training;

- specialised treatment, care and or support services;

- partnerships and networks;

- a monitoring and evaluation system;

- a feedback and report back system; and

- provisions for review and adaptation (Cape Gateway, 2004:3-4; DaimlerChrysler, 2005; Department of Labour, 2003; DPSA, 2002:31; James, 2005:28-9; NIR, 2006; Rau, 2004:9).

Because of length constraints, the findings about the nature and contents of each of these components will not be elaborated upon here. The results will instead be integrated into the final profile of an "ideal" programme.

\section{THE COMPONENTS OF AN “IDEAL” HIV AND AIDS WORKPLACE PROGRAMME: PRACTICE}

The interview schedule that was utilised to ascertain the 33 participants' views of the nature of an "ideal" workplace programme was structured according to four themes. These were the background of their current programme, its key components, its key success factors and biggest 
impediments, and their views on the future development of the programme. These themes, as well as the initial and core follow-up questions that were utilised, are listed in Table 2.

TABLE 2

THE STRUCTURE AND CONTENT OF THE INTERVIEW SCHEDULE

\begin{tabular}{|c|c|}
\hline & Initial questions and core follow-up questions \\
\hline The & ne 1: Background of the HIV and AIDS workplace programme \\
\hline & Please describe the background and development of your programme. \\
\hline 1.1 & How long has the programme been in place and when/how did it start? \\
\hline 1.2 & How many employees are being served? \\
\hline 1.3 & Who is directly responsible for managing the programme? \\
\hline & Where does the programme manager fit into your organisational structure? \\
\hline The & ne 2: Key components/essential nature of the HIV and AIDS workplace programme \\
\hline & Please describe the key components/ essential nature of your programme \\
\hline & To what extent do the following issues play a part in your programme?: \\
\hline & Components of the workplace programme; \\
\hline & Policy; \\
\hline & Management involvement and strategies; \\
\hline & Communication; \\
\hline & Prevention; \\
\hline & Education and training; \\
\hline & Partnerships and networks; \\
\hline & Monitoring and evaluation. \\
\hline $\begin{array}{l}\text { Ther } \\
\text { prog }\end{array}$ & $\begin{array}{l}\text { ne 3: Key success factors and critical impediments in the HIV and AIDS workplace } \\
\text { ramme }\end{array}$ \\
\hline & $\begin{array}{l}\text { What, specifically, are the key success factors of your HIV and AIDS workplace } \\
\text { programme? }\end{array}$ \\
\hline & $\begin{array}{l}\text { What, specifically, are the major impediments that you have to face in the } \\
\text { implementation of your HIV and AIDS workplace programme? }\end{array}$ \\
\hline Ther & ne 4: Future developments/a view ahead \\
\hline & $\begin{array}{l}\text { Are there any plans for future changes to the programme and programme } \\
\text { management? }\end{array}$ \\
\hline & Where do you see your HIV and AIDS workplace programme 5 years from now? \\
\hline
\end{tabular}

The interviews lasted an average of 75 minutes and, depending on the participants' responses, could cover a total of 27 core questions. Their responses were transcribed and analysed in order to delineate what the participants saw as the strong points/success factors and the weak points/critical impediments of their workplace programmes. Their expressed views were then used as an indicator of each factor's priority rating. Next, the resulting data were structured according to the ten identified categories of components. It should be noted that none of the respondents highlighted any success factor for three of these components (Table 3: components 8-10). Component 2, again, produced six sub-categories of success factors (Table 3). 


\section{TABLE 3}

\section{THE SUCCESS FACTOR STRONG POINTS IN THE RESPONDENTS' WORKPLACE PROGRAMMES}

\begin{tabular}{|c|c|c|c|}
\hline Components/categories of success factors/strong points & $\begin{array}{l}\text { Responses/ } \\
\text { respondents } \\
(\mathbf{n}=33)\end{array}$ & $\begin{array}{l}\text { Total re- } \\
\text { sponses per } \\
\text { category }\end{array}$ & $\begin{array}{l}\text { Percentages } \\
\quad(\%) \text { of } \\
\text { respondents }\end{array}$ \\
\hline Component 1: HIV and AIDS policy & & 3 & $9.1 \%$ \\
\hline 1.1 Approved HIV and AIDS policy & 2 & & \\
\hline $\begin{array}{l}\text { 1.2 Approved wellness policy (that includes an HIV } \\
\text { and AIDS component) }\end{array}$ & 1 & & \\
\hline \multicolumn{4}{|l|}{$\begin{array}{l}\text { Component 2: Management and management } \\
\text { involvement and strategies }\end{array}$} \\
\hline Category 1: Positive contribution of management & & 9 & $27.27 \%$ \\
\hline 2.1.1 Positive involvement of top management & 3 & & \\
\hline 2.1.2 Positive commitment from management & 6 & & \\
\hline $\begin{array}{l}\text { Category 2: Type of programme that management } \\
\text { succeeded in creating }\end{array}$ & & 21 & $63.64 \%$ \\
\hline $\begin{array}{ll}\text { 2.2.1 Functions according to an approved business } \\
\text { plan }\end{array}$ & 1 & & \\
\hline $\begin{array}{l}\text { 2.2.2 The programme is flexible, client orientated, } \\
\text { accessible and or well positioned }\end{array}$ & 10 & & \\
\hline Programme is based on research & 2 & & \\
\hline 2.2.4 Programme was launched in the "correct" way & 2 & & \\
\hline $\begin{array}{ll}2.2 .5 & \begin{array}{l}\text { It forms part of an overall EAP/Wellness } \\
\text { programme }\end{array} \\
\end{array}$ & 3 & & \\
\hline $\begin{array}{ll}2.2 .6 & \text { Recognition provided to programme } \\
\text { coordinators and peer educators }\end{array}$ & 1 & & \\
\hline 2.2.7 $\quad$ Staff is empowered at ground level & 2 & & \\
\hline Category 3: Adequate budget and human resources & & 16 & $48.48 \%$ \\
\hline 2.3.1 Programme has an adequate budget & 9 & & \\
\hline $\begin{array}{ll}\text { 2.3.2 } & \text { Resources (e.g. e pap, immune booster, } \\
\text { electronic equipment) are made available/ } \\
\text { utilised }\end{array}$ & 3 & & \\
\hline 2.3.3 Well staffed & 1 & & \\
\hline 2.3.4 Provision is made for care for the caregiver & 2 & & \\
\hline 2.3.5 Positive involvement of volunteers & 1 & 0 & \\
\hline $\begin{array}{l}\text { Category } 4: \text { Positive traits of the programme } \\
\text { manager }(s) / \text { coordinator( }(s)\end{array}$ & & 10 & $30.3 \%$ \\
\hline $\begin{array}{l}\text { 2.4.1 Exhibits passion and commitment for the } \\
\text { programme }\end{array}$ & 6 & & \\
\hline 2.4.2 Has specialised knowledge on HIV and AIDS & 3 & & \\
\hline 2.4.3 Is HIV positive & 1 & & \\
\hline Category 5: Positive contribution of peer educators & & 15 & $45.45 \%$ \\
\hline 2.5.1 Actively involved peer educators & 12 & & \\
\hline 2.5.2 Well selected peer educators & 2 & & \\
\hline Incentives for peer educators & 1 & & \\
\hline
\end{tabular}




\begin{tabular}{|c|c|c|c|}
\hline Components/categories of success factors/strong points & $\begin{array}{c}\text { Responses/ } \\
\text { respondents } \\
(\mathbf{n}=33)\end{array}$ & $\begin{array}{c}\text { Total re- } \\
\text { sponses per } \\
\text { category }\end{array}$ & $\begin{array}{l}\text { Percentages } \\
(\%) \text { of } \\
\text { respondents }\end{array}$ \\
\hline $\begin{array}{l}\text { Category 6: Positive contribution for organised } \\
\text { labour/trade unions }\end{array}$ & & 7 & $21.21 \%$ \\
\hline Component 3: Communication and marketing & & 7 & $21.21 \%$ \\
\hline $\begin{array}{l}\text { 3.1 Specific marketing plan and associated material } \\
\text { is in existence }\end{array}$ & 5 & & \\
\hline Marketing material is available (but no plan) & 1 & & \\
\hline $3.3 \quad$ HIV calendar days are celebrated & 1 & & \\
\hline Component 4: Prevention/awareness & & 13 & $39.39 \%$ \\
\hline $\begin{array}{l}\text { 4.1 Systematic awareness raising of HIV and AIDS } \\
\text { is done* }\end{array}$ & 9 & & \\
\hline The prevention programme is transparent & 2 & & \\
\hline 4.3 Condoms are made available & 2 & & \\
\hline Component 5: Education and training & & 9 & $27.27 \%$ \\
\hline $\begin{array}{l}\text { 5.1 Comprehensive education and training on HIV } \\
\text { and AIDS are provided } * *\end{array}$ & 9 & & \\
\hline Component 6: Treatment/care/support & & 12 & $36.36 \%$ \\
\hline 6.1 Sufficient number of active support groups & 5 & & \\
\hline VCT $^{*}$ is available & 3 & & \\
\hline Positive participation in VCT & 4 & & \\
\hline Component 7: Partnerships and networks & & 14 & $42.42 \%$ \\
\hline $\begin{array}{ll}7.1 & \begin{array}{l}\text { Positive involvement of external service } \\
\text { providers }\end{array}\end{array}$ & 8 & & \\
\hline Positive support from IDU & 2 & & \\
\hline $\begin{array}{ll}\text { 7.3 Service providers are paid for deliverables (no } \\
\text { salary) }\end{array}$ & 4 & & \\
\hline Component 8: Monitoring and evaluation & \multicolumn{3}{|c|}{$\begin{array}{l}\text { Not mentioned as a success factor/strong } \\
\text { point }\end{array}$} \\
\hline Component 9: Feedback and reporting & \multicolumn{3}{|c|}{$\begin{array}{l}\text { Not mentioned as a success factor/strong } \\
\text { point }\end{array}$} \\
\hline Component 10: Review and adaptation & \multicolumn{3}{|c|}{$\begin{array}{l}\text { Not mentioned as a success factor/strong } \\
\text { point }\end{array}$} \\
\hline
\end{tabular}

* The respondents did not always draw a distinction between training and awareness-raising initiatives.

** Voluntary counselling and testing.

The implications of the responses as contained in Table 3 will not be discussed separately. They will instead be integrated into the requirements that an "ideal" programme should meet.

\section{THE PROFILE OF AN "IDEAL" HIV AND AIDS WORKPLACE PROGRAMME}

In order to arrive at a profile of an "ideal" HIV and AIDS workplace programme for South African circumstances, the findings of the literature study were combined with the outcomes of the structured interviews. The results were then used to design a model of an "ideal" programme. This model (Diagram 1) consists of both the components that should constitute such an endeavour and the general process that should be followed in its development and 
implementation. It is based on the premise that such programmes are not static, but rather continuing evolving entities.

DIAGRAM 1

A MODEL OF AN “IDEAL" HIV AND AIDS PROGRAMME

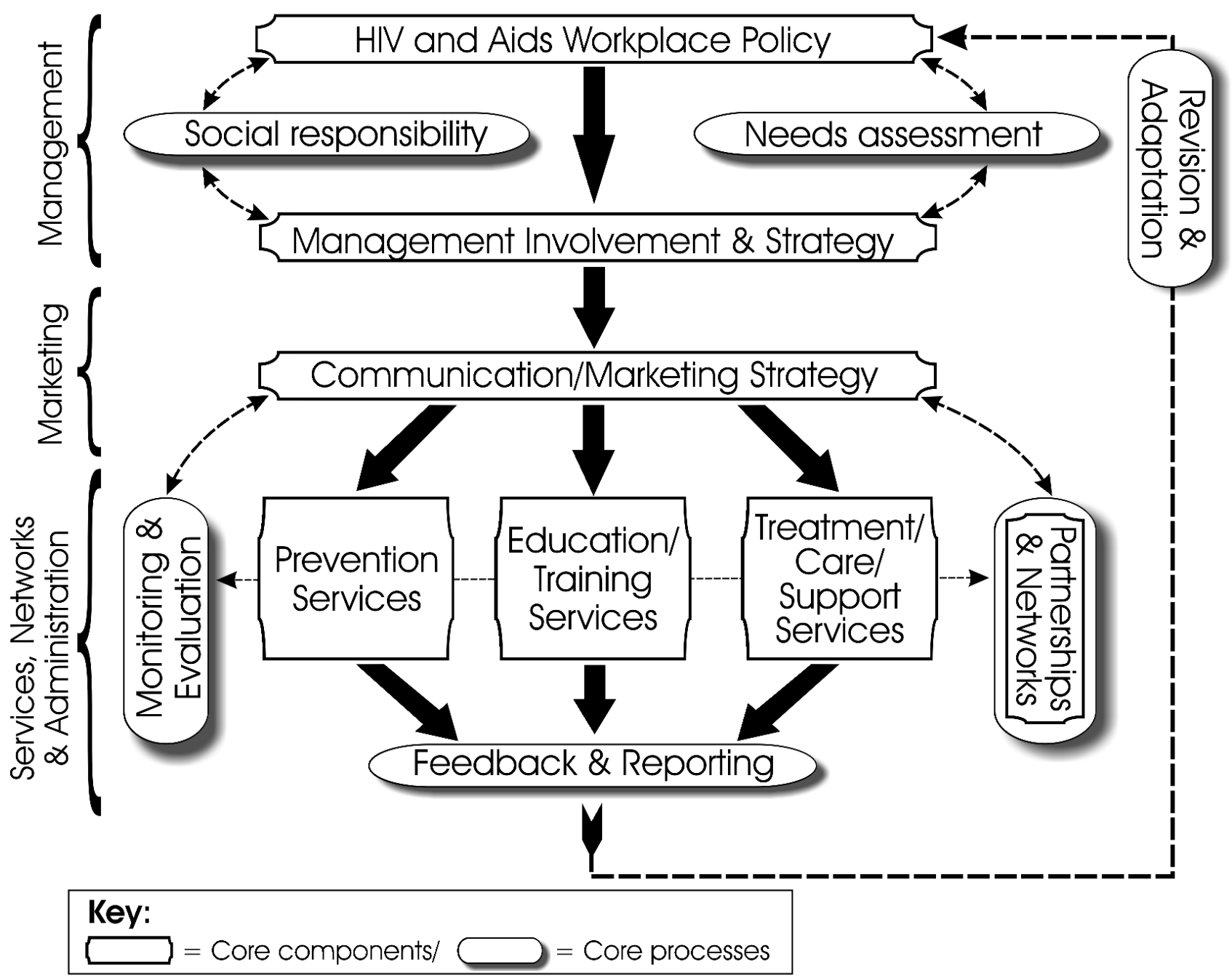

In the model of an "ideal" workplace programme (Diagram 1), the broad programme management field was divided into two components and three core processes. These are the HIV and AIDS workplace policy, management involvement and strategies, social responsibility, needs assessments, and programme revision and adaptation.

The model's point of departure is that it would be practically impossible to design and implement an effective workplace programme without the existence of a sound HIV and AIDS policy. Such a policy should be based on (ongoing) needs assessment and a clear understanding and acceptance of the organisation's social responsibility as far as HIV and AIDS issues are concerned. The policy should culminate in a written management strategy and business plan (Diagram 1).

A clear and effective marketing or communication strategy is deemed such a core success factor in the implementation of workplace programmes that it is demarcated as a separate component. Such a strategy should not only cover the different types of services that are rendered, but also the HIV and AIDS workplace policy, management's commitment to it and 
the core "ideas" that should become entrenched (Bryant, McCormack-Brown, McDermott, Forthofer, Bumpus, Calkins \& Zapata, 2007:154-159).

In the model (Diagram 1) the continuum of workplace services were divided, for analytical purposes, into three components. These are prevention (e.g. awareness raising, condom distribution and commemoration of special days), education/training (e.g. capacity building, ongoing training and peer education) and treatment/care/support (e.g. voluntary counselling and testing (VCT) support groups, individual counselling and bereavement counselling). The effectiveness of these services is often dependent on partnerships and networks with internal and especially external systems. Hence the direct link between the service components and this facet of a programme (Diagram 1).

Monitoring and evaluation, together with feedback and reporting, could be viewed as important processes in the day-to-day administration of workplace programmes (Diagram 1). In this context monitoring refers to the systematic and continuous assessment of a programme over a period of time, whereas evaluation entails the assessment of the form and performance of its components against one or more standards (Stake, 2004:4). The rationale for monitoring and evaluation is to assess whether or not they are (still) appropriate, cost effective and able to meet set objectives (DPSA, 2002:86).

The results of the administration process should be reported to management and used as a basis for the revision and adaptation of the HIV and AIDS policy and its implementation. This would complete the first cycle of an ongoing development and implementation process.

\section{REQUIREMENTS THAT AN HIV AND AIDS WORKPLACE PROGRAMME SHOULD MEET}

For clarification purposes, the different components of, and processes within, an ideal HIV and AIDS workplace programme will be discussed separately. In this exposition they will collectively be known as "requirements" because of the view that they represent the minimum requirements for success. The results of the empirical study will be incorporated into this discussion.

\section{Requirement 1: An HIV and AIDS policy}

An HIV and AIDS policy can in this context be described as a written document that sets out an organisation's position on HIV and AIDS, and the systems it will put in place to deal with the consequences of the pandemic (Rau, 2004:35). It should be the result of consultation between top management and all the relevant stakeholders.

The policy should ideally contain the following:

- The organisation's position on HIV and AIDS in terms of its vision and mission, management's commitment to deal with the issue, guarantees of confidentiality and the organisation's position on voluntary counselling and testing (VCT);

- A demarcation of the organisation's legal rights and obligations;

- A demarcation of its social responsibility (this could include the extent to which it would involve and take responsibility for employee's families and "external" communities);

- Details of its HIV and AIDS-related employment policies (e.g. position regarding HIV testing, employee benefits, performance management, the Safety, Health and Environmental (SHE) measures that will be taken and the procedures to be followed to determine medical incapacity and dismissal); 
- Express standards of behaviour expected of the employer, the employees and trade unions in order to create a caring, non-discriminatory and stigmatisation-free environment, as well as appropriate measures to deal with deviations from these standards (e.g. an grievance procedure);

- An outline of the HIV and AIDS workplace programme;

- The means of communication within the organisation on HIV and AIDS issues;

- Details of employee assistance available to persons infected and affected by HIV and AIDS;

- Details of implementation and coordination responsibilities and monitoring and evaluation mechanisms (DaimlerChrysler, 2005; Department of Labour, 2003:45; DPSA, 2002:490; ILO, 2001; NIR, 2006; SANS, 2007:2).

There are various international guidelines and legal obligations that should be taken into consideration in the formulation of the policy. The most important of these are discussed next.

\section{International guidelines}

There are especially three international guidelines that inform South African HIV and AIDS workplace programmes and policies. These are the International Labour Organisation's (2001) Code of Practice on HIV/AIDS and the World of Work, UNAIDS's (1996) International Guidelines on HIV/AIDS and Human Rights and the Southern African Development Community's (1997) Code of Good Practice on HIV/AIDS and Employment.

\section{The ILO Code of Practice on HIV/AIDS and the World of Work (2001)}

The International Labour Organisation's code provides the following guidelines for all employers and employees in the private and public sector:

- HIV and AIDS must be recognised as a workplace issue;

- Responses to HIV and AIDS must be based on the principle of non-discrimination;

- Gender equality must be pursued as part of any HIV and AIDS response;

- Every employee has a right to a healthy and safe working environment;

- Communication between employers, workers, their representatives, government and PLWAs must take place on HIV and AIDS issues;

- No HIV screening of employees or job applicants;

- Every employee has the right to confidentiality regarding their HIV status;

- Workers must be enabled to continue working for as long as possible;

- The workplace must promote HIV prevention;

- Care and support should be provided to infected workers (ILO, 2001:3-18).

The UNAIDS International Guidelines on HIV/AIDS and Human Rights (1996)

The UNAIDS guideline will be especially helpful for the creation of a policy that emphasises a positive, rights-based response to HIV and AIDS, and the obligations that state and other institutions should meet (DPSA, 2002:19; UNAIDS, 1996:37-51).

\section{The SADC Code of Good Practice on HIV/AIDS and Employment (1997)}

The Southern African Development Community's (SADC) Code was developed through a consultative tripartite process and adopted at a meeting of the SADC ministers of labour in Pretoria in August 1997. The code is not a legally binding document, but all signatories agreed: 
- that the national and regional implications of the HIV and AIDS epidemic required regional employment standards; and

- that all member countries should develop tripartite national codes reflected in national law (DPSA, 2002:19).

\section{South African legislation}

In South Africa every workplace response to the epidemic must be based on an understanding of the rights of persons infected and affected by HIV and AIDS. The basis of this is found in the Bill of Rights in the Constitution. It protects the rights of every person to, amongst other things, the right to equality, dignity, privacy and fair labour practices (South African Constitution, Act 108 of 1996b: Section 23(1)). The constitution is the supreme law of the country and all other laws must comply with it.

There are also a number of important labour statutes, though only one of them, the Employment Equity Act (Act 55 of 1998a), specifically refers to HIV and AIDS. This Act, as well as some of the others that should be taken into account in the formulation of an HIV and AIDS policy, will only be briefly discussed.

\section{The Employment Equity Act (Act 55 of 1998a)}

Act 55 of 1998 aims to ensure equality and non-discrimination in the workplace. It has two clauses that specifically refer to HIV and AIDS. These prohibit any unfair discrimination based on "HIV status" and HIV testing without Labour Court authorisation.

\section{The Labour Relations Act (Act 66 of 1995)}

The Labour Relations Act regulates the relationship between employees, trade unions and employers. Especially its regulations pertaining to the resolution of disputes between employers and employees and the rights of workers with regard to dismissals are of importance to the HIV and AIDS issue.

\section{The Occupational Health and Safety Act (Act 29 of 1996a)}

Act 29 of 1996 obliges all employers to ensure that the working environment is safe and healthy for employees. It requires, inter alia, that employers must provide safety equipment in the workplace. In the case of the SAPS it could include equipment such as gloves that should be used on, for example, accident scenes in order to protect the wearer from accidental infection through contaminated blood.

\section{The Compensation for Occupational Injuries Act (Act 130 of 1993)}

The Compensation for Occupational Injuries Act gives every employee the right to apply for compensation if injured in the course and scope of their employment. This would include compensation for HIV infection if it can be proven that the employee was infected at the workplace (DPSA, 2002:19-20).

\section{The Promotion of Equality and the Prevention of Unfair Discrimination Act (Act 4 of 2000)}

This act sets out measures for dealing with various forms of unfair discrimination and inequality in the workplace. It applies to all agencies, including those not covered by existing labour legislation (e.g. the SANDF, the Secret Service and the National Intelligence Agency) and provides protection against discrimination towards employees living with HIV and AIDS. 


\section{The Medical Schemes Act (Act 131 of 1998b)}

Act 131 of 1998 requires that a medical aid scheme may not, directly or indirectly, unfairly discriminate against any person on the basis of their HIV status. It also allows the Minister of Health to gazette a minimum standard of benefits to be provided to members of medical schemes (DPSA, 2002:19-21).

In the empirical research most participants did not give a high priority rating to the availability of an HIV and AIDS policy as a success factor (Table 3). They tended to see it as such a "normal" part of a workplace programme that it did not need any highlighting. However, the opposite also held true. The lack of a (comprehensive) policy was viewed as the biggest obstacle to an effective response to the epidemic (Simbayi, Skinner, Letlape \& Zuma, 2005:134).

\section{Requirement 2: A social responsibility foundation}

An organisation's perception of its social responsibility must be integrated into its HIV and AIDS policy (Diagram 1). It should be kept in mind that no government authority, company or civic group alone can address all of the HIV and AIDS issues in a community. This requires a collaborative response from all role-players and a willingness to live out its social responsibility. In this context social responsibility can be defined as an organisation's contribution to, and support of, community HIV and AIDS prevention and care efforts. Such responses should have two main focuses, one internal and the other external. The internal response encompasses what an organisation can do in response to HIV and AIDS in its own workplace. The external response refers to recognising and exploiting the comparative advantage that organisations have in "making a difference" to the general nature and course of the epidemic (Department of Labour, 2003:39).

The empirical study did not provide any coherent picture of the extent of the represented organisations' social responsibility. Some demarcated their responsibility to "personnel who are infected or affected by HIV and AIDS", others tacitly included the staff's family members while still others, such as DaimlerChrysler (2005), considered broader community involvement as an integral part of its strategy (DaimlerChrysler, 2005). This trend somewhat contradicts the view that an organisation's involvement in HIV and AIDS should go beyond its gates into surrounding communities and organisations (Rau, 2004:11,71).

\section{Requirement 3: Needs-assessment based}

Needs assessment plays a dual role in HIV and AIDS workplace programmes. It should, firstly, be done even before a programme is designed and implemented. This will place the programme on a scientific base and ensure that it addresses the specific needs and circumstances of all those involved. It should also form an integral part of the cyclical programme development and implementation process (Diagram 1). This would ensure that activities and interventions are and remain relevant.

There are important questions that should be asked and answered during needs assessments. These include: Who is the assessment attempting to inform? What is the purpose of the needs assessment? Whose needs are to be assessed? How will the information be used? What resources are available to do the needs assessment? (Cavanagh \& Chadwick, 2007; ISUE, 2001). Some of the easier assessment techniques that could be utilised in arriving at appropriate answers are the following: 
- Secondary analysis can be utilised to extract HIV and AIDS-related data from existing reports and information on the functioning of the organisation and its employees (De Vos, 2005:378);

- Attitude surveys can be used to gather information from a representative sample of the organisation's staff members. This can take the form of telephone surveys and personal interviews;

- A quick and fairly accurate technique is the use of key informants (De Vos, 2005:379). It is especially useful if decision makers can be identified and used for the prioritisation of needs and concerns;

- Focus group interviews can be an especially helpful assessment technique. Steps should, however, be taken to ensure that the staff members are selected for their particular skills and experience on HIV and AIDS-related issues (ISUE, 2001).

Needs assessments are not only important for the identification of personnel members' specific HIV and AIDS awareness, education and treatment/support services needs; they can also inform policy and decisions regarding the allocating of funds and other resources (Diagram 1).

Needs assessment, however, was not highlighted as a success factor by any of the respondents in the empirical study. Two $(6.1 \%)$, however, indicated that their programmes were research based (Table 3). From these and other responses it was concluded that the vast majority of the programmes covered in the study came into existence in an reactive way, mostly as a result of political and societal pressure. Research and especially needs assessments also did not play an important role in their further development.

\section{Requirement 4: Management involvement and strategies}

One of the major tasks of an organisation's management would be to formulate the strategies it would follow to deal with HIV and AIDS workplace issues (DPSA, 2002:41). Such a strategy should, especially, operationalise the organisations policy by:

- stating the management's commitment to the "HIV and AIDS cause";

- specifying the goal and expected outcomes of the organisation's HIV and AIDS-related services and activities;

- detailing the structures that would be established and utilised (this could include the person/body that would be responsible to organise, coordinate and manage the workplace programme);

- stipulating the procedures that would be followed (these could include the mechanisms through which needs assessments, monitoring, feedback, reporting and revisions would be done, as well as their associated time frames) (Diagram 1);

- describing the links that would exist between the HIV and AIDS programme and the core functions of the organisation, as well as between its overall strategic planning and that pertaining to HIV and AIDS;

- indicating which resources, both human and financial, would be allocated to the programme;

- detailing how the effects of HIV and AIDS on the organisation and its staff would be managed (e.g. through human resource policies, processes, planning and management, as well as the management of employee benefits); 
- specifying the management's stance towards the establishment of partnerships with "external" role-players in the HIV and AIDS field (DPSA, 2002:37, 45; ILO, 2007:1; SANS, 2007:7).

Almost all the participants indicated that one or more of the elements that make up an HIV and AIDS strategy contributed significantly to the success of their workplace programmes. These include the commitment and involvement of management $(9 ; 27.3 \%)$, the resources that they invested in the service $(16 ; 48.48 \%)$ and the type of programme they succeeded in creating (21; 63.64\%) (Table 3). Two elements, however, received scant mention. They were the link between the organisation's core functions and its HIV and AIDS programme, and the link between its overall strategic planning and that pertaining to HIV and AIDS. The overall impression was that managements seemed to view and administer the workplace programmes as a separate entity separate from their core functions, viz. as an externally enforced nonessential obligation.

\section{Requirement 5: A communication and marketing strategy}

According to the literature, a comprehensive and effective communication and marketing strategy is a prerequisite for an effective HIV and AIDS workplace programme (Bryant et al., 2007:154-159). This strategy should ensure that:

- all staff members know and understand the organisation's HIV and AIDS policy, as well as its related structures and procedures;

- employees are aware of the different types of services that are available to them and motivate them to make use of or become involved in these services;

- mechanisms are in place that would facilitate dialogue between the role-players and ensure that the programme is "owned" by those involved;

- all HIV and AIDS-related communication within the workplace takes the language, educational level, literacy and culture of the employees, as well as the structure and culture of the organisation, into account (Bryant et al., 2007:154-9; DPSA, 2002:101; Foundation for Professional Development, 2006:35).

From the analysis of the interviews it emerged that respondents were of the opinion that a wellformulated and actively implemented communication and marketing plan is especially of importance in large or geographically dispersed organisations. This opinion, however, contradicts the state of the art knowledge on the subject, which views such a strategy as a quintessential part of all programmes (Bryant et al., 2007:154-159).

\section{Requirement 6: Prevention services}

A comprehensive HIV and AIDS/STI prevention strategy and programme should in principle be viewed as one of the cornerstones of an effective workplace programme. It should comprise a variety of ongoing, coordinated activities and services aimed at the changing of high-risk behaviour and thus prevent new HIV infections (DPSA, 2002:75; Rau, 2004:45). It would typically consist of the following elements:

- Awareness-raising activities such as displays, pamphlets and the commemoration of special days;

- Voluntary counselling and testing (VCT) services on either an on-site or referral basis;

- Peer education activities and the training of other key personnel;

- Condom distribution and the promotion of condom use; 
- The optimal management of STIs as part of a workplace health service or through referral to services in the community;

- An infection-control programme specifically focusing on health care providers; and

- The promotion of a non-discriminatory environment (Department of Labour, 2003:54; DPSA, 2002:75).

The research showed that $13(39.4 \%)$ of the participants rated their prevention services as a critical success factor (Table 3). In the light of the prominent role that prevention (still) has to play, this was somewhat lower than expected. It also emerged that the interviewees did not draw a distinction between awareness raising and education, but rather saw the latter as the primary mechanism to prevent further infections. This trend, coupled with other data generated by the interviews, showed that respondents perceived prevention as extremely important, but admitted that their programmes were not always up to par in this regard.

\section{Requirement 7: Education and training services}

Education and training are one of the most important mechanisms through which the goals of a workplace programme are reached. They can take on a wide variety of forms. These include:

- the education of all at-risk personnel;

- the (ongoing) training of HIV and AIDS coordinators;

- the training of peer educators in the ways in which they could assist with the implementation of the programme;

- the provision of skills to employees, managers, supervisors, trade union representatives, personnel officers and occupational social workers on how to respond to HIV and AIDS issues (this includes the rights of the infected and affected employee and the legal requirements of $\mathrm{VCT}$ ); and

- generally creating awareness of the latest research findings in the field of HIV and AIDS (DPSA, 2002:75; Huisamen, 2005:35; SANS, 2007:7).

Nine $(27.27 \%)$ of the respondents viewed their education and training services as a critical success factor (Table 3). This is in line with the findings on prevention services.

\section{Requirement 8: Treatment/care/support services}

Not only is the workplace an ideal setting for HIV and AIDS prevention and education, but also appropriate for the provision of some type of treatment, care and/or support to infected and affected employees.

In this context the concept "treatment" is used in its more "clinical" form and refers to the steps that can be taken to strengthen the infected individual's immune system so that he/she can be kept healthy for as long as possible. It also covers treating opportunistic infection, caring for general health problems and the use of anti-retroviral therapy (Van Dyk, 2001:366).

Care encompasses both physical and psychosocial care. Any care programme should be holistic, compassionate and person-centred (Fahmer, 1988:115). Most of the difficulties that HIV-infected employees experience are familiar to social and health care professionals, because the psychosocial and physical needs of people with AIDS are often similar to those of other terminally ill patients (Van Dyk, 2001:366).

The support structures created by means of workplace programmes can take on a variety of forms. These include individual therapy or counselling, as well as the utilisation of various 
types of support groups. Such groups have already been created by various NGOs and some government departments (Van Dyk, 2001:251). If none are available in a specific community, staff members can also be encouraged to form their own. The following are, according to the World Health Organisation (WHO, 1990:32-33), the typical issues that can be dealt with in peer support groups:

- Learning to live with HIV infection;

- Dealing with feelings of loneliness, depression, powerlessness and suicide;

- Advice about sexual relations and the implication of safer sex behaviour;

- Development of life skills;

- Planning for the future.

Support should be available on a one-on-one basis as well as in group context. Where possible, provision should be made for bereavement counselling for the family and support for those who are openly living with the HI virus. Emphasis should be placed on the wellness of the employee, looking at people in a holistic way and mechanisms that could be used to deal with stigma and people's feelings of isolation (UNAIDS, 2005:37).

The empirical research indicated vast differences in the role that treatment/care/support services play in different organisations. Eight of the 11 SAPS participants (i.e. 72.7\%) saw such services as an important success factor. This should be seen against the background of the fact that Police Social Work Services had established 20 support groups in the Gauteng province to ensure support for people affected by, or infected with, the virus. The respondents from other organisations indicated that they found it difficult to establish and maintain such groups.

\section{Requirement 9: Partnerships and networks}

The literature indicates that successful HIV and AIDS programmes are usually the product of collaborative action that involves partnerships with all relevant role-players (Department of Labour, 2003:62-63; Rau, 2004:7; UNAIDS, 2003:56). There are numerous benefits to such partnerships. These include a more comprehensive approach to the pandemic, the pooling of resources and expertise of different types of organisations and sectors, improved coordination between services and more appropriate referrals amongst organisations (Department of Labour, 2003:62). Not only does this avoid unnecessary duplication of effort and maximise the impact of scarce resources, but also fosters a spirit of cooperation rather than the jealousy and rivalry that is very real in some locations (UNAIDS, 2003:56).

The respondents in the empirical research also placed the availability and use of partnerships and networks amongst the top 50\% of success factors in their workplace programmes (Table 3). They indicated that especially the utilisation of "external" service providers enabled them to link their staff members to the specialised services that they were not always able to render.

\section{Requirement 10: Monitoring and evaluation}

There are various types of formal and informal monitoring and evaluation mechanisms that could be employed. Informal feedback can be gained through suggestion boxes and conversation with co-workers. Organisation meetings can also be used to assess employee's acceptance of each component of the programme. In such meetings shop stewards and supervisors can contribute views on the acceptability of the programme and perceived changes in attitudes (Rau, 2004:60). 
More formal feedback can be achieved through various types of research. These include workplace HIV prevalence surveys, HIV and AIDS risk assessments and KAPB (knowledge, attitude, practices/behaviour) assessments (DPSA, 2002:108). Use can also be made of indicators such as:

- the number of condoms distributed;

- the number of peer and other educators trained;

- the number, levels and percentage of all employees who have been trained;

- the level of awareness that exists amongst employees;

- the number of STIs that have been treated;

- the number of employees that have requested VCT (DPSA, 2002:108).

None of the participants mentioned the inclusion of a monitoring and evaluation system in their workplace programmes as a strength. Most tended to see such a system as a "normal" part of the day-to-day running of their programmes. It also emerged from the interviews, however, that some organisations did not have any formal or comprehensive system in place.

\section{Requirement 11: Feedback and reporting}

A workplace programme should include specifications for, and requirements regarding, feedback and reporting (Diagram 1). It is usually required that all key role-players such as managers, HIV and AIDS coordinators and peer educators should participate in this process and that reports should be submitted on a monthly, quarterly and/or annual basis. In the case of government departments, all annual reports must include information on their HIV and AIDS programmes and activities (DPSA, 2002:110).

The Department of Public Service and Administration (DPSA, 2002:107) recommends that HIV and AIDS should be included as a standing agenda item in the meetings of senior management and also included as an indicator in their performance agreements (DPSA, 2002:107). Developing such a performance measure can, however, be a complex task. It could include that managers must:

- agree on the results that their departments intend to achieve;

- decide on the outputs that are to be measured;

- set realistic output targets against which to measure HIV and AIDS-related performance; and

- determine the process and format that performance reporting on HIV and AIDS would take (DPSA, 2002:109).

As in the case of monitoring and evaluation, all respondents in the research saw feedback and reporting as a "normal" part of managing their programmes. There were, however, strong indications that reporting tended to be a one-way process and that practitioners tended to receive very little feedback on the reports that they presented to (top) management.

\section{Requirement 12: Review and adaptation}

Top management should review an organisation's HIV and AIDS management system at planned, regular intervals (Diagram 1). The purpose of such a step would be to ensure that a programme is still suitable, adequate and effective, and that the policies that govern the process are still relevant. It should also take changes in prevalence rates, new knowledge on prevention 
and treatment, and new opportunities for the improvement of services and partnerships into consideration.

The review process should especially focus on:

- the results of internal audits and the extent to which they comply with the legal and other requirement to which they subscribe;

- the relevance of the organisation's current HIV and AIDS policy and the changes that are required;

- how well (or badly) the HIV and AIDS programme's management had performed;

- the extent to which objectives and targets have been met;

- the status of corrective and preventive actions;

- the extent to which follow-up actions from previous management reviews have been completed;

- changing circumstances, including developments in legal and other requirements regarding HIV and AIDS-related services; and

- recommendations for improvements (Naude, 2008:44; SANS, 2007:9).

From the responses of the participants in the empirical research it emerged that, although their workplace programmes are subject to review and adaptation, these are not done at set intervals. The tendency is rather to react to events within the organisation or to changes in government policy or society in general.

\section{MAIN FINDINGS AND RECOMMENDATIONS}

One of the aims of the study on which this article is based was to use the existing literature and the views of key informants to formulate a profile of an HIV and AIDS workplace programme that would meet the requirements and circumstances of the South African work environment. It especially attempted to identify the required constituent components of such a programme, as well as their relative priorities.

The interviews with key informants showed that the successes of their programmes could be attributed especially to eight factors. These critical success factors should receive priority attention in the development of any such programmes; they were:

- the positive contribution of (top) management;

- an adequate budget;

- the provision of adequate human resources;

- extensive networks and partnerships with other organisations;

- the contribution by peer educators;

- a comprehensive prevention programme;

- effective treatment, care and support services; and

- a passionate and committed programme director/coordinator.

There were, however, major gaps in the success factors espoused by the respondents and those contained in the literature. These included:

- the role of an HIV and AIDS policy;

- the articulation of the organisation's social responsibility; 
- the utilisation of needs assessments; and

- the administrative procedures that are followed (e.g. monitoring, evaluation, feedback, reporting, review and adaptation).

Most respondents did not mention the above as success factors or as major impediments. From an analysis of the data they provided, it emerged that this trend could be attributed to one of two reasons. In some cases they accepted these factors as a "normal" part of a workplace programme. In the majority of cases, however, the factors were not expressly or fully present in their particular organisations. This latter trend could be seen as an indication of serious deficiencies in the South African workplace response to the epidemic.

Although it was not the intention of the study to do an evaluation of South African HIV and AIDS workplace programmes, it inadvertently indicated that most of these programmes should be subjected to thorough scientific evaluation.

One of the elements that has until now been missing in attempts to evaluate workplace programmes was some type of instrument that could be used to benchmark existing efforts. The model of an "ideal" HIV and AIDS workplace programme as contained in this article could fill this gap. Its framework and contents could be utilised as criteria in much-needed organisationspecific programme evaluation research or simply as a benchmarking instrument. It could also be used as a guideline for other organisations that are in the process of developing new programmes. This will ensure a comprehensive and integrated service that will be beneficial to the employer as well as to the overall wellbeing and productivity of the employee and the community.

\section{REFERENCES}

\section{ACTS OF LEGISLATION see SOUTH AFRICA (REP)}

BRYANT, C.A., McCORMACK-BROWN, K.R., McDERMOTT, R.J., FORTHOFER, M.S., BUMPUS, E.C., CALKINS, S.A. \& ZAPATA, L.B. 2007. Community-based prevention marketing. Health Promotion Practice, 8(2):154-163.

CAPE GATEWAY. 2004. Workplace HIV/AIDS policy. Available: http://www.capegateway. gov.za/eng/directories/glossary [Accessed: 12/02/2007].

CAVANAGH, S. \& CHADWICK, K. 2007. Health needs assessment at a glance. Available: http:www.nice.org.uk [Accessed: 08/10/2007].

DAIMLERCHRYSLER SOUTH AFRICA. 2005. DaimlerChrysler HIV/AIDS workplace policy. Available: http://www.iolhivAIDS.co.za [Accessed: 14/02/2007].

DE VOS, A.S. 2005. Programme evaluation. In: DE VOS, A.S. (ed) Research at grass roots: for the social sciences and human service professions $\left(3^{\text {rd }}\right.$ ed). Pretoria: Van Schaik Publishers.

DELPORT, C.S.L. 2005. Quantitative data-collection methods. In: DE VOS, A.S. (ed) Research at grass roots: for the social sciences and human service professions $\left(3^{\text {rd }}\right.$ ed). Pretoria: Van Schaik Publishers.

DEPARTMENT OF LABOUR see SOUTH AFRICA (REP), DEPARTMENT OF LABOUR. DPSA see SOUTH AFRICA (REP), DEPARTMENT OF PUBLIC SERVICE AND ADMINISTRATION. 
FAHMER, R. 1988. Nursing interventions. In: LEWIS, A. (ed) Nursing care of the person with AIDS/ARC. Rockville (Maryland): Aspen.

FOUCHÉ, C.B. 2005. Qualitative research designs. In: DE VOS, A.S. (ed) Research at grass roots: for the social sciences and human service professions $\left(3^{\text {rd }} \mathrm{ed}\right)$. Pretoria: Van Schaik Publishers.

FOUNDATION FOR PROFESSIONAL DEVELOPMENT. 2006. Multisectoral HIV \& AIDS programme management. Lynnwood Ridge: Foundation for Professional Development.

GRINNELL, R.M. 2001. Social work research and evaluation $\left(6^{\text {th }}\right.$ ed). Belmont: Wadsworth/Thomson Learning.

HUISAMEN, P. 2005. Die effek van die besluitnemings- en lewensdoelkomponente van die SAPD se Selfbestuur Personeelkapasiteitsbouprogram. (The effect of the decision-making and purpose-in-life components of the SAPS Self-Management Personnel Capacity-Building programme.) Potchefstroom: North-West University. (PhD Thesis)

ILO see INTERNATIONAL LABOUR ORGANISATION.

INTERNATIONAL LABOUR ORGANISATION. 2001. An ILO code of practice on HIV/AIDS and the world of work. Geneva: ILO.

INTERNATIONAL LABOUR ORGANISATION. 2007. Starting a workplace programme. Available: $\quad$ http//www.oit.org/public/English/protection/trav/AIDS/steps/step-5 [Accessed: 14/02/2007].

IOWA STATE UNIVERSITY EXTENSION. 2001. Needs assessment strategies for community groups and organizations. Available: http://www.extension.iastate.edu/communities/tools/assess [Accessed: 04/10/2007].

ISUE see IOWA STATE UNIVERSITY EXTENSION.

JAMES, R. 2005. Building organisational resilience to HIV and AIDS: implications for capacity building. Oxford: INTRAC.

NATIONAL COUNCIL OF SWEDISH INDUSTRY (NIR). 2006. Swedish Workplace HIV/AIDS Programme (SWHAP). Available: http://www.nir.se/swedish workplace hiv AIDS_programme(1) [Accessed: 14/02/2007].

NAUDE, A. 2008. An evaluation of the HIV/AIDS workplace programme of the South African Police Service (SAPS). Potchefstroom: North-West University. (PhD Thesis)

NIR see NATIONAL COUNCIL OF SWEDISH INDUSTRY (NIR).

RAU, B. 2004. Workplace HIV and AIDS programs: an action guide for managers. Arlington, VA: Family Health International.

SADC. 1997. SADC code of good practice on HIV/AIDS and employment. Available: http/www.hri.ca/partners/alp [Accessed: 13/06/2007].

SANS see SOUTH AFRICAN NATIONAL STANDARD.

SIMBAYI, L., SKINNER, D., LETLAPE, L. \& ZUMA, K. 2005. Workplace policies in public education. Cape Town: HSRC Press. 
SOUTH AFRICA (REP) 1993. Compensation for Occupational Injuries Act (130/1993). Pretoria: Government Printer.

SOUTH AFRICA (REP) 1995. Labour Relations Act (66/1995). Pretoria: Government Printer.

SOUTH AFRICA (REP) 1996a. Occupational Health and Safety Act (29/1996). Pretoria: Government Printer.

SOUTH AFRICA (REP) 1996b. South African Constitution Act (108/1996). Pretoria: Government Printer.

SOUTH AFRICA (REP) 1998a. Employment Equity Act (55/1998). Pretoria: Government Printer. Ditto

SOUTH AFRICA (REP) 1998b. Medical Schemes Act (131/1998). Pretoria: Government Printer.

SOUTH AFRICA (REP) 2000. Promotion of Equality and the Prevention of Unfair Discrimination Act (4/2000). Pretoria: Government Printer.

SOUTH AFRICA (REP), DEPARTMENT OF LABOUR. 2003. HIV \& AIDS technical assistance guidelines. Cape Town: Formeset.

SOUTH AFRICA (REP), DEPARTMENT OF PUBLIC SERVICE AND ADMINISTRATION. 2002. Managing HIV \& AIDS in the workplace. Pretoria: Department of Public Service and Administration.

SOUTH AFRICAN NATIONAL STANDARD. 2007. HIV and AIDS management systems - general requirements. Pretoria: Standards South Africa.

STAKE, R.E. 2004. Standards-based \& responsive evaluation. London: Sage Publications.

UNAIDS. 1996. HIV/AIDS and human rights - international guideline. Geneva: Office of the United Nations High Commissioner tot Human Rights \& the Joint United Nations Programme on HIV/AIDS.

UNAIDS. 2003. Best practice collection: where there's a will there's a way. Geneva: UNAIDS.

UNAIDS. 2005. Best practice collection: access to treatment in the private sector workplace. Geneva: UNAIDS.

VAN DYK, A. 2001. HIV \& AIDS care \& counselling. Cape Town: Pearson Education.

WEYERS, M.L. \& VAN DEN BERG, A.M. 2006. The success factors in community work services: a critical incident study. International Social Work, 49(2):177-187.

WHO see WORLD HEALTH ORGANISATION.

WORLD HEALTH ORGANISATION. 1990. Guidelines for counselling about HIV infection and disease (AIDS Series No 8). Geneva: WHO.

Dr Annemarie Naude, social worker in private practice; Prof Mike Weyers, Social Work Division, School for Psychosocial Behavioural Sciences, North-West University, Potchefstroom Campus, South Africa. 